\title{
Cultivar, Ground-cover, and Irrigation Treatments and Their Interactions Affect Long-term Performance of Peach Trees
}

\author{
Richard E.C. Layne, Chin S. Tan, and David M. Hunter \\ Research Station, Agriculture Canada, Harrow, Ont. NOR I GO, Canada
}

Additional index words. blossom intensity, canker, defoliation, fruiting attributes, hardiness, photosynthesis, Prunus persica, soil water content, tree survival, trunk cross-sectional area

\begin{abstract}
Three cultivars ('Garnet Beauty', 'Harbrite', 'Canadian Harmony'), two ground covers (temporary cover vs. permanent sod), and no irrigation vs. season-long trickle irrigation were studied in a high-density (633 trees/ha) peach [Prunus persica (L.) Batsch] orchard established on Fox sand in 1980. From 1985 to 1989, soil water content in the top 130 $\mathrm{cm}$ was similar in nonirrigated and trickle-irrigated plots except during the growing season (May to September). Total soil water was lowest in nonirrigated plots that had permanent sod strips in the row middles and fell below the-permanent wilting point for $\geq 11$ months in summer but not at depths below $130 \mathrm{~cm}$. Trunk cross-sectional area (TCA) was greater for 'Canadian Harmony' and 'Harbrite' than 'Garnet Beauty', ground-cover treatments had no effect, and irrigated trees were generally larger than those not irrigated. Photosynthetic rate and stomatal conductance differed by cultivar, were unaffected by ground cover, and were enhanced by irrigation. Defoliation differed by cultivar, ground cover had little effect, and irrigation usually delayed defoliation. Flower bud and shoot xylem hardiness differed by cultivar but not by ground cover and were generally enhanced by irrigation. Tree survival was significantly affected by cultivar, being best with 'Harbrite' and 'Canadian Harmony' and poorest with 'Garnet Beauty'. Permanent sod enhanced tree survival while trickle irrigation reduced it. Cumulative marketable yields were affected more by cultivar than by ground cover or irrigation. 'Canadian Harmony' had the highest yield, followed by 'Harbrite', then 'Garnet Beauty'. Yields in sod were slightly higher than in temporary cover and yields with trickle irrigation were slightly higher than without irrigation. The best soil-management system when TCA, marketable yield, and tree survival were considered was a combination of permanent creeping red fescue sod strips in the row middles and trickle irrigation in the tree row. This system is being recommended to commercial growers in southwestern Ontario.
\end{abstract}

Various components must be successfully integrated into the design of an intensive, highly productive peach orchard management system suitable for climatic zones near the northern limit of commercial culture in North America (Layne and Tan, 1988). Some important components include the proper choice of adapted cultivars (Layne, 1984, 1991), an appropriate system of groundcover management (Glenn and Welker, 1989; Hogue and Neilsen, 1987; Layne and Tan, 1988; Marks et al., 1973; Townshend et al., 1984; Welker and Glenn, 1988), and supplemental irrigation (Chalmers et al., 1981, 1983; Daniell, 1982; Layne and Tan, 1984, 1988; Layne et al., 1986; Reeder et al., 1979; Tan and Layne, 1991).

The effects of stress factors accumulate with tree age, especially after peach orchards come into full production, and negatively affect tree growth, fruit production, fruit size, disease response, cold hardiness, root distribution, and tree survival (Biggs, 1989; Chalmers et al., 1981, 1983; Dhanvantari, 1978; Layne, 1984; Layne and Tan, 1984, 1988; Layne et al., 1986; Tan and Layne, 1991). Thus, long-term experiments are necessary to assess cumulative treatment effects and interactions adequately in orchard management experiments (Layne and Tan, 1984).

In 1980, an experiment was initiated to study the responses of early-, mid- and late-season peach cultivars to differing groundcover and irrigation treatments in southwestern Ontario. The results of the first 5 years, which included orchard establishment and the first 3 years of production, were reported earlier (Layne and

Received for publication 13 May 1992. Accepted for publication 22 May 1993. We acknowledge the excellent technical assistance of E.W. Larnoure, H.O. Jackson, A. Cornelisse, and M.D. St. Pierre and the statistical advice of V.A. Dirks. The cost of publishing this paper was defrayed in part by the payment of page charges. Under postal regulations, this paper therefore must be hereby marked advertisement solely to indicate this fact.
Tan, 1988). The cumulative effects of the treatments for the second 5 years, which include the years of full and declining production, are presented here.

\section{Materials and Methods}

Details of this experiment were described by Layne and Tan (1988). Briefly, the experiment was established on Fox sand that comprised $89 \%$ sand, $8 \%$ silt, $3 \%$ clay, $\mathrm{pH}$ 6.1, with a field capacity (FC) of $16.8 \%$ (volume basis), permanent wilting point (PWP) of $6.5 \%$, and bulk density of $1.65 \mathrm{~cm}^{3}$ (Layne et al., 1986). Soil water content was monitored using a subsurface neutron moisture probe (model 501; Campbell Pacific, Martinez, Calif.). Aluminum tubes were inserted in the middle of the four-tree plots and $\approx 1.5 \mathrm{~m}$ from the tree trunk to a depth of $260 \mathrm{~cm}$ (near the water table). The measurements were taken twice per month in summer and monthly in spring and fall at $20-\mathrm{cm}$ intervals to a depth of $260 \mathrm{~cm}$. The neutron probe was calibrated against gravimetric sampling using the following calibration equation: $\theta_{\mathrm{v}}:=0.368 \mathrm{R} / \mathrm{R}_{\mathrm{w}}-0.06$, where $\theta_{v}$ is the volumetric water content which is the product of the gravimetric determination and the bulk density of soil; $\mathrm{R}$ is the actual count rate in the soil; and $\mathrm{R}_{\mathrm{w}}$ is the standard count of the probe in the shield.

The design was a split-split plot in a randomized complete block with five replications and four trees per cultivar for each experimental unit. An early-season ('Garnet Beauty'), mid-season ('Harbrite'), and late-season ('Canadian Harmony') cultivar, each propagated on Siberian C peach seedling rootstock, comprised the main-plot treatments. Ground-cover treatments were assigned to the subplots. The temporary ground-cover treatment is the standard method used in Ontario and consisted of clean cultivation from April to June followed by a seeded cover crop of Italian rye 
grass (Lolium multiflorium Lam.) in the row middles from July to March. The other ground-cover treatment comprised permanent sod strips of creeping red fescue (Festuca rubra L.) in the row middles. The irrigation treatments were assigned to the sub-subplots and consisted of no irrigation (the commercial standard) and full-season trickle irrigation in the tree row with two vortex emitters per tree (flow rate $=4.5$ liters $\cdot h^{-1}$ ) located $0.6 \mathrm{~m}$ from the tree base on the north and south side of each tree. Available soil water (ASW) $(\mathrm{FC}-\mathrm{PWP})$ in the irrigated zone of irrigated plots was held between $80 \%$ and $100 \%$ of FC. During the growing season, plots were trickle-irrigated daily. The irrigation schedule in 1985 was the same as in 1984 (Layne and Tan, 1988), namely, 27 liters/day per tree from 23 May to 15 June, 36 liters/day per tree from 16 June to 15 July, and 54 liters/day per tree from 16 July to 6 Sept. Beginning in 1986 and continuing through 1989, the daily volume of water used (liters/day per tree) by month was as follows: 54 (May), 72 (June), 81 (July), 81 (August). Irrigation was terminated following harvest of the late-season cultivar. The irrigation schedule from 1986 to 1989 was that for mature peach trees (Tan and Layne, 1990). All irrigated trees received the same amount of water in any given year.

Tree rows were oriented north to south to optimize light interception. Trees were spaced $3.05 \mathrm{~m}$ in the row and $5.18 \mathrm{~m}$ between rows to provide a density of 633 trees/ha. A guard row of 'Cresthaven'/'Siberian C' surrounded each replication. All trees were trained to a modified central leader. Weeds in the tree row were controlled with one or more seasonal applications of 1,1-dimethyl-4,4-bipyridinium salts (paraquat). Each year 190.5 $\mathrm{kg}$ of $0 \mathrm{~N}-10 \mathrm{P}-30 \mathrm{~K}$ fertilizer per hectare was broadcast in the spring. A banded application of $\mathrm{NH}_{4} \mathrm{NO}_{3}(34 \mathrm{~N}-0 \mathrm{P}-0 \mathrm{~K})$ at the drip line of each tree was made annually in April. The rate for plots in temporary cover in 1985 was $0.34 \mathrm{~kg} /$ tree and increased by 0.06 $\mathrm{kg} \cdot$ year $^{-1}$ from 1986 to 1989 . Corresponding rates for plots in permanent sod were $0.68 \mathrm{~kg} / \mathrm{tree}$ and increased by $0.16 \mathrm{~kg} \cdot \mathrm{year}^{-1}$.

Growth measurements, fruit thinning, harvest, and grading methods were as described by Layne and Tan (1988). Tree survival was recorded each fall. Annual subjective ratings were made of winter injury, canker (Leucostoma spp.), blossom intensity, fruit set before thinning, and time of defoliation.

The apparent net photosynthetic $\mathrm{CO}_{2}$ uptake rate $(\mathrm{Pn})$ and stomatal conductance on nonfruiting shoots were determined using a portable photosynthesis system (LI-6000, LI-COR, Lincoln, Neb.). The leaf area under test, held constant by using inserts in a 1-liter cuvette, was $10 \mathrm{~cm}^{2}$. A fully expanded leaf oriented perpendicular to incident sunlight was enclosed in the cuvette and allowed to stabilize for $30 \mathrm{sec}$ before data were recorded for $40 \mathrm{sec}$. During the stabilization and recording periods, leaves were held perpendicular to the incident sunlight. Photosynthesis rates were measured between 9:30 AM and 12:30 PM on cloud-free or uniformly hazy days when photosynthetic photon flux density exceeded $1200 \mu \mathrm{mol} \cdot \mathrm{m}^{-2} \cdot \mathrm{s}^{-1}$, Measurement dates were 24 and 31 July 1986; 15,23, and 28 July 1987; and 17 June, 6 and 22 July 1988.

Controlled freezing tests were performed in 1985, 1988, and 1989 on apical fruiting shoots of the previous season's growth using the methods of Layne (1989). Shoots for the 1985 and 1989 tests were collected in mid-December and artificially acclimated for 21 days at $-3 \mathrm{C}, 7$ days at $-5 \mathrm{C}$, and 7 days at $-10 \mathrm{C}$ to attain maximum hardiness levels before the freezing tests. In 1988, the shoots were collected in February while still dormant and held for 6 days at $-10 \mathrm{C}$ before controlled freezing. The temperature required to kill $50 \%$ of the flower buds $\left(\mathrm{T}_{50} \mathrm{FB}\right)$ and $50 \%$ of the shoot xylem $\left(\mathrm{T}_{50} \mathrm{SX}\right)$ was determined according to the methods of Bittenbender and Howell (1974).
Each data set, consisting of plot totals rather than plot means, was tested by analysis of variance (ANOVA) as a split-split plot in a randomized complete block. Plot totals for yields were expressed on a land area rather than on a per tree basis. Missing values for missing trees were not calculated and plot totals were not adjusted for missing trees.

\section{Results}

Soil water content. The total soil water content was monitored from January 1985 to the end of August 1989 when the experiment was terminated following harvest of 'Canadian Harmony' (Figs. 1 and 2). Soil water content in the top $130 \mathrm{~cm}$ (Fig. 1) was similar in irrigated and nonirrigated plots from January to April and again from October to December in all years. Divergence in soil water content between irrigated and nonirrigated plots usually began in May, increased to a maximum in August, then converged between late August and October. During the growing season, nonirrigated plots with sod strips in the row middles occasionally had lower levels of total soil water in the top $130 \mathrm{~cm}$ than those without sod strips, and both levels were usually significantly lower than in the irrigated plots (Fig. 1). The 1985 to 1988 growing seasons were drier than in 1989, a phenomenon that led to greater divergence in total soil water between irrigated and nonirrigated plots than in 1989. The lowest soil water levels recorded from 1985 to 1989 were associated with nonirrigated plots that had permanent sod strips in the row middles. Soil water levels in these plots fell below the PWP (Fig. 1) each year, except in 1987 and 1989. In 1985, they were below the PWP in June, July, and August, but only in August in 1986. In 1988, they were below the PWP only in June and July. In 1989, the wettest year, the experiment was terminated in August.

The total soil water content from 130 to $230 \mathrm{~cm}$ in the soil profile (Fig. 2) showed that a divergence in soil water content occurred between irrigation treatments only in 1985, 1987, and 1988. The nonirrigated plots, as expected, had the driest soil, but there were no differences between ground-cover treatments as also observed from 0 to $130 \mathrm{~cm}$ deep (Fig. 1). The total soil water in nonirrigated plots fell below the PWP only in 1 year (1985) and not during the most active part of the growing season (Fig, 2).

Trunk cross-sectional area (TCA). Cumulative TCA, on a perplot basis as an index of fruit bearing surface, increased with tree age for all cultivars (data not presented). After 10 years of growth (1989), 'Harbrite' and 'Canadian Harmony' TCA was larger than that of 'Garnet Beauty'. Ground-cover treatments had only minor and inconsistent effects on TCA. Trees in irrigated plots had consistently higher TCAS than those not irrigated.

When the growth data (1985-89) were averaged by cultivar for the four possible combinations involving ground-cover and irrigation treatments, permanent sod with irrigation gave the highest TCA with 'Garnet Beauty' while temporary cover with irrigation gave the highest TCA with 'Harbrite' and 'Canadian Harmony'. These treatment combinations were $53.7 \%, 12.9 \%$, and $26.6 \%$ higher, respectively, than commercial practices (temporary cover without irrigation).

$P n$. The Pn rate of 'Canadian Harmony' was generally $\approx 20 \%$ lower than that of 'Garnet Beauty' or 'Harbrite' (Table 1). Rates in 1988, a hot dry year, were lower than in 1987 and 1986. Sod cover had no effect on Pn. Irrigated trees had a higher Pn in 1986 than those not irrigated, but in 1987 and 1988 there were no differences between irrigated and nonirrigated trees. Treatment effects on stomatal conductance were similar to those noted for photosynthesis (data not presented). 


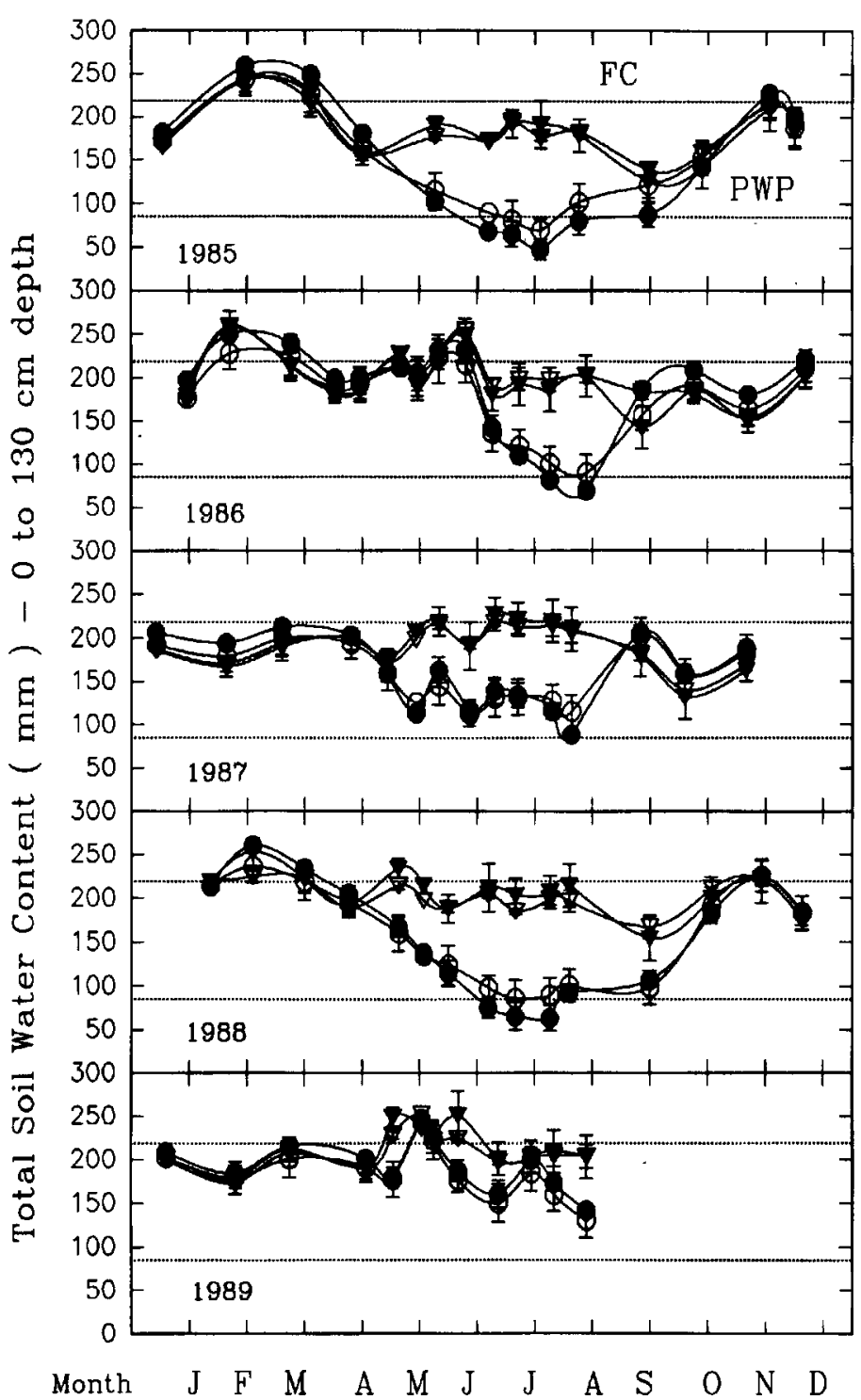

Fig. 1.Total soil water content in the soil profile from 0 to $130 \mathrm{~cm}$ as influenced by various treatment combinations during 1985 to 1989 . The four treatment combinations were no irrigation and temporary cover $(\mathrm{O})$, no irrigation and permanent sod (O), irrigation and temporary cover $(\Delta)$, and irrigation and permanent $\operatorname{sod}(\boldsymbol{\nabla}))$. FC $=$ field capacity, PWP $=$ permanent wilting point. Error bars are the SES of means,

Defoliation. There was a significant cultivar effect on time of defoliation in 1985, 1986, and 1987 but not in 1988 (data not presented). 'Garnet Beauty' was the earliest to defoliate, 'Canadian Harmony' was intermediate, and 'Harbrite' defoliated last. Ground cover did not affect time of defoliation in 1986 or 1987 , however, in 1985 defoliation was more advanced with temporary cover than with permanent sod, while in 1988 this effect was reversed. Nonirrigated trees defoliated faster than irrigated trees.

Winter injury and canker ratings. Cultivar, ground-cover, or irrigation treatments did not affect annual winter injury ( 1985-89) or canker incidence $(1985,1986,1988,1989)$ (data not presented). In 1987, however, 'Canadian Harmony' had the least canker while 'Garnet Beauty' and 'Harbrite' had similar but more severe canker. Trees in sod treatments had less canker than those in temporary cover. There was less canker in nonirrigated than irrigated treatments. No treatment interactions were significant in any year.

Cold hardiness of FB and SX. FB hardiness, measured by $\mathrm{T}_{50}$, differed among cultivars in 1985, 1988, and 1989 (Table 2). The

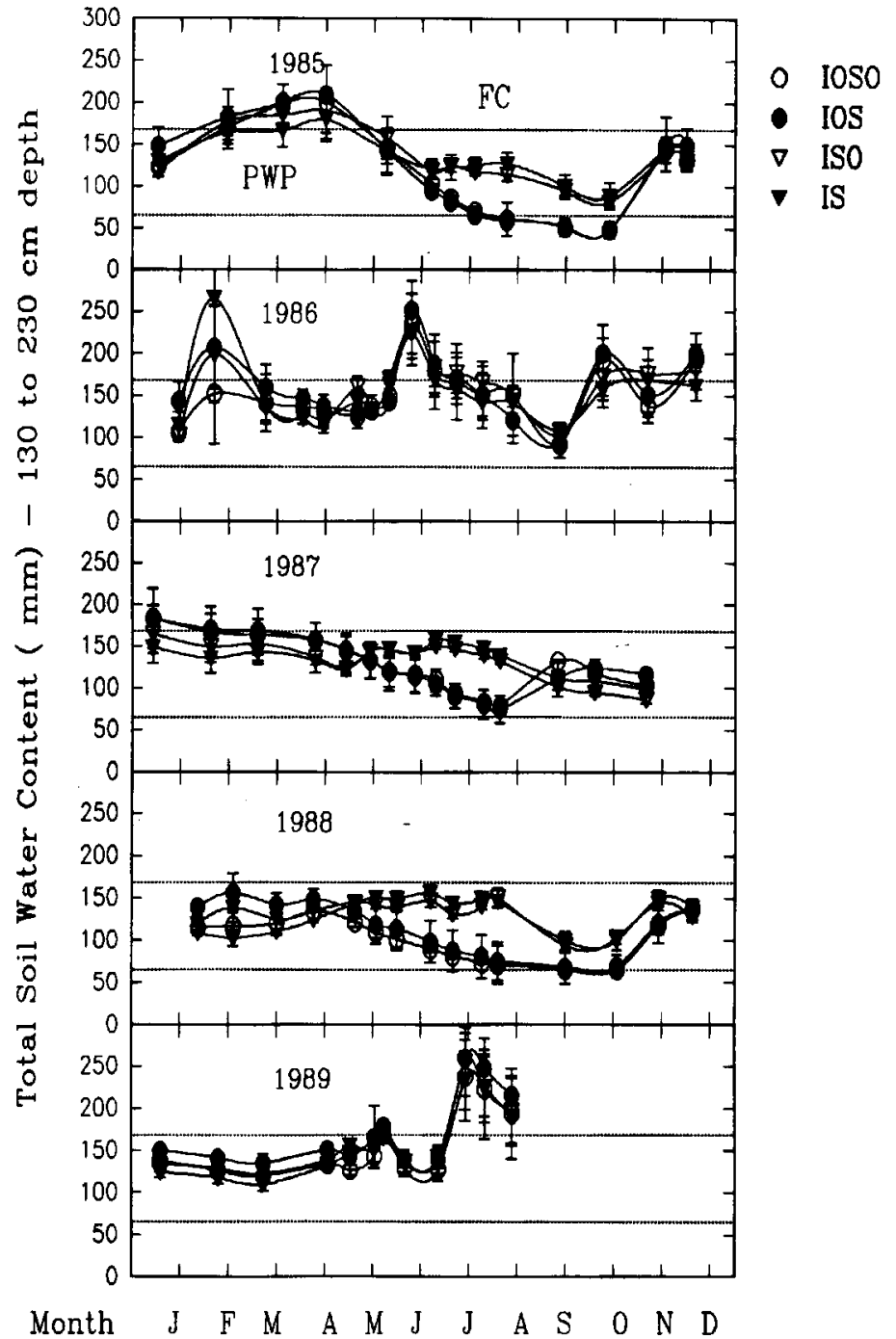

Fig. 2. Total soil water content in the soil profile from 130 to $230 \mathrm{~cm}$ as influenced by various treatment combinations during 1985 to 1989 . The four treatment combinations were no irrigation and temporary cover $(\mathrm{O})$, no irrigation and permanent sod $(\circlearrowleft)$, irrigation and temporary cover $(\Delta)$, and irrigation and permanent sod $(\mathbf{\nabla})$.Error bars are the SES of means.

Table 1. Effect of cultivar, ground-cover, and irrigation treatments on apparent net photosynthetic rate $(\mathrm{Pn})$ of peaches.

\begin{tabular}{lccc}
\hline \hline & \multicolumn{3}{c}{$\mathrm{Pn}\left(\mathrm{mg} \mathrm{CO}_{2} / \mathrm{m}^{2}\right.$ per sec $)$} \\
\cline { 2 - 4 } Treatment & 1986 & 1987 & 1988 \\
\hline Main plots & 0.61 & 0.62 & 0.53 \\
$\quad$ Garnet Beauty & 0.60 & 0.67 & 0.52 \\
Harbrite & 0.46 & 0.56 & 0.42 \\
Canadian Harmony & $\mathrm{NS}$ & $\mathrm{NS}$ & $*$ \\
F test & & & \\
Subplots & 0.56 & 0.62 & 0.49 \\
No sod & 0.56 & 0.62 & 0.49 \\
Sod & $\mathrm{NS}$ & $\mathrm{NS}$ & $\mathrm{NS}$ \\
F test & & & \\
Sub-subplots & 0.53 & 0.62 & 0.50 \\
No irrigation & 0.59 & 0.62 & 0.49 \\
Trickle irrigation & $*$ & $\mathrm{NS}$ & $\mathrm{NS}$ \\
F test & &
\end{tabular}

${ }_{\text {Ns, }}^{*}$ Nonsignificant or significant at $P \leq 0.05$ respectively. 
fruiting shoots tested were produced the previous growing seasons. 'Harbrite' and 'Garnet Beauty' usually had hardier buds than 'Canadian Harmony'. The ground-cover treatments did not affect bud hardiness. Flowerbuds were slightly more hardy in nonirrigated than in irrigated plots in 1985 and 1988 but not in 1989 .

Cultivars also differed significantly in SX hardiness. In 1985, 'Canadian Harmony' was the hardiest, 'Harbrite' was intermediate, and 'Garnet Beauty' was the least hardy. In 1988, 'Harbrite' was hardiest, 'Garnet Beauty' was intermediate, and 'Canadian Harmony' was least hardy. In 1989, 'Harbrite' was more hardy than 'Garnet Beauty' or 'Canadian Harmony', which were equally hardy. There was no ground-cover effect on SX hardiness. In 1988, irrigated trees had hardier SX than those not irrigated. A smaller but similar effect was noted in 1985, while in 1989, nonirrigated trees were hardier.

Tree survival. In this experiment, most, if not all, tree losses were the result of a combination of canker infection (Leucostoma spp.) and winter injury. Tree survival declined from the sixth (1985) to the 10th (1989) year (Fig. 3). During this period, the annual minimum temperatures and dates of occurrence were 26.0C (21 Jan. 1985), -20.5C (15 Jan. 1986), -21.0C (25 Jan. 1987), and -20.5C (12 Dec. 1988). Trees were removed in Fall 1989 before low, injurious temperatures occurred. From 1985 to 1987, the cultivar effect (Fig. 3) on tree survival was small, but increased dramatically in 1988 and 1989 for 'Garnet Beauty', the early-season cultivar. There was a consistent difference in tree survival in response to the two ground-cover treatments, with trees in permanent sod showing better survival than trees with temporary cover in the row middles. Trees in nonirrigated plots survived better than those in irrigated plots.

A significant ground-cover $\times$ irrigation interaction was obtained for tree survival in 1985. Although permanent sod treatments responded similarly, regardless of irrigation treatment, tree survival with temporary cover was better with irrigation than without. In 1986, there were significant cultivar $\times$ ground-cover and cultivar $\times$ irrigation interactions. 'Garnet Beauty' and 'Canadian Harmony' showed increased survival with sod vs. temporary cover, while the opposite effect was obtained with 'Harbrite'. Survival of 'Garnet Beauty' was better with irrigation than with-

Table 2. Effect of cultivar, ground-cover, and irrigation treatments on maximum cold hardiness of peach flower buds $\left(\mathrm{T}_{50} \mathrm{FB}\right)$ and shoot xylem $\left(\mathrm{T}_{50} \mathrm{SX}\right)$ in 1985,1988 , and $1989 .{ }^{\mathrm{z}}$

\begin{tabular}{|c|c|c|c|c|c|c|}
\hline \multirow[b]{3}{*}{ Treatments } & \multicolumn{6}{|c|}{$\mathrm{T}_{50}\left({ }^{\circ} \mathrm{C}\right)$} \\
\hline & \multicolumn{2}{|c|}{1985} & \multicolumn{2}{|c|}{1988} & \multicolumn{2}{|c|}{1989} \\
\hline & FB & SX & FB & SX & FB & SX \\
\hline \multicolumn{7}{|l|}{ Main plots } \\
\hline Garnet Beauty & -29.8 & -31.9 & -23.3 & -25.1 & -25.0 & -28.2 \\
\hline Harbrite & -29.1 & -32.7 & -23.5 & -25.9 & -25.3 & -28.6 \\
\hline Canadian Harmony & -28.0 & -33.0 & -20.1 & -24.4 & -24.4 & -28.3 \\
\hline$F$ test & $* *$ & $* *$ & $* *$ & * & $* *$ & NS \\
\hline \multicolumn{7}{|l|}{ Subplots } \\
\hline No sod & -29.0 & -32.5 & -22.2 & -25.2 & -24.9 & -28.3 \\
\hline Sod & -29.0 & -32.6 & -22.3 & -25.1 & -24.9 & -28.3 \\
\hline $\mathrm{F}$ test & NS & NS & NS & NS & NS & NS \\
\hline \multicolumn{7}{|l|}{ Sub-subplots } \\
\hline No irrigation & -29.2 & -32.5 & -22.4 & -24.9 & -24.9 & -28.4 \\
\hline Trickle irrigation & -28.8 & -32.6 & -22.2 & -25.3 & -24.9 & -28.3 \\
\hline$F$ test & $* *$ & NS & NS & $*$ & NS & NS \\
\hline
\end{tabular}

${ }^{2}$ Tests conducted on dormant, acclimated shoots of the previous season's growth, respectively.

${ }^{\mathrm{Ns}}, *, * *$ Nonsignificant or significant at $P \leq 0.05$ or 0.01 , respectively. out, the opposite response occurring with 'Harbrite' and 'Canadian Harmony'. Again in 1989, there was a significant cultivar $\times$ ground-cover interaction, the response being similar to that obtained in 1986.

When the data for the four soil-management treatment combinations were averaged by cultivar over the 5 years from 1985 to 1989 , there was no single treatment combination that was optimum for all three cultivars (data not presented). Thus, for 'Garnet Beauty', tree survival was best with permanent sod plus irrigation $(82.5 \%)$ and poorest with temporary cover plus irrigation $(50.0 \%)$. For 'Harbrite', tree survival was best in temporary cover without irrigation $(85 \%)$ and poorest with permanent sod strips plus irrigation $(67.5 \%)$. For 'Canadian Harmony', tree survival was best with permanent sod minus irrigation $(95 \%)$ and poorest with temporary cover plus irrigation $(67.5 \%)$.

Blossom intensity. There was a significant cultivar effect on blossom intensity ratings in each of the 5 years (data not presented). 'Harbrite' usually had the heaviest bloom, 'Garnet Beauty' was intermediate, and 'Canadian Harmony' had the lightest bloom. Blossom intensity was higher with permanent sod than temporary cover in 1985, 1987, 1988, and 1989. Irrigation increased blossom intensity in 1987 and 1988, but the opposite effect was noted in 1985 and 1986. There was no effect of irrigation on blossom intensity in 1989.

Only in 1987 was there a significant cultivar $\times$ irrigation treatment interaction; 'Garnet Beauty' and 'Canadian Harmony' showed lower blossom intensity with irrigation than without, while 'Harbrite' had similar blossom intensity with or without irrigation.

Fruit set before thinning. Only in 1985 and 1989 (data not

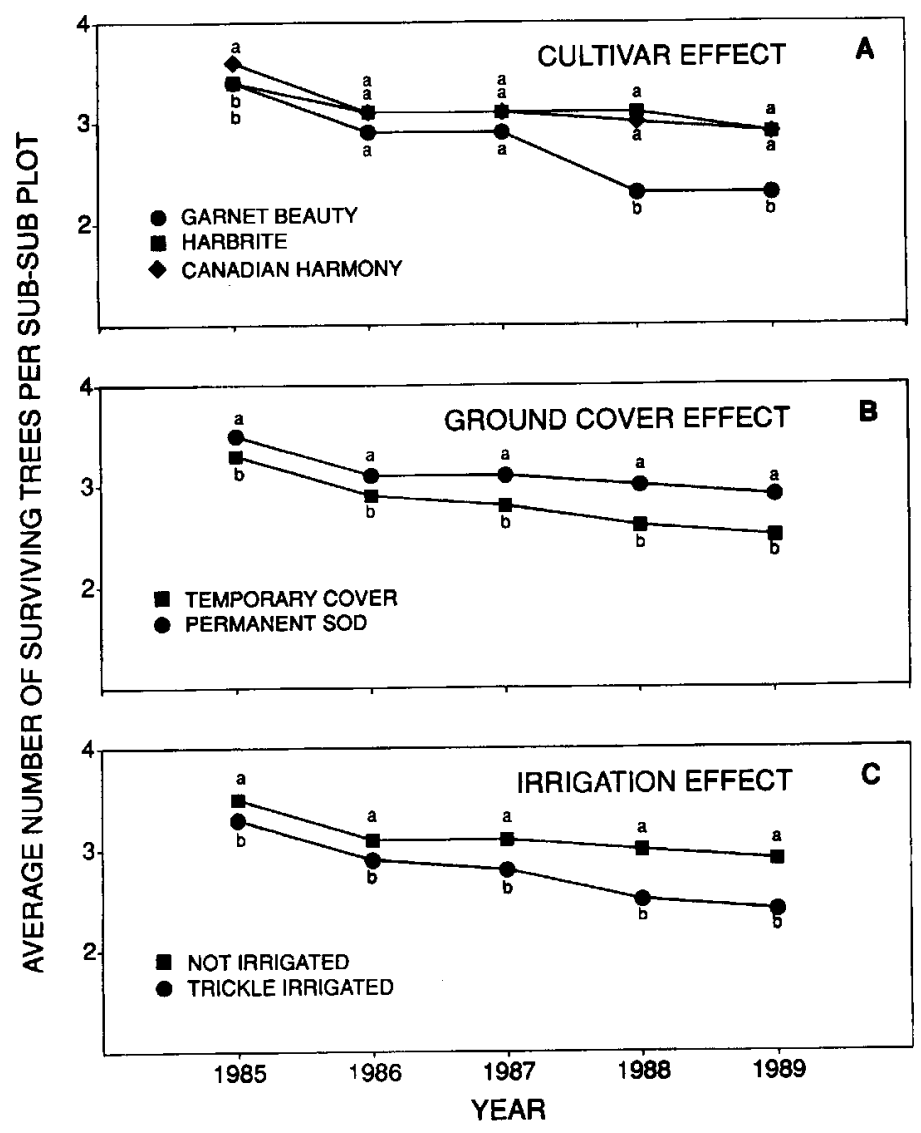

Fig. 3. Effect of cultivar (A), ground cover (B), and irrigation (C) treatments on peach tree survival from 1985 to 1989 . Mean separation within years within treatments by SES. 
presented) were there significant cultivar effects on fruit set, its being highest with 'Harbrite', intermediate with 'Garnet Beauty', and lowest with 'Canadian Harmony'. Fruit set was higher in sod vs. temporary cover in 1985, 1988, and 1989 but was similar in 1986 and 1987. Fruit set was significantly enhanced by irrigation in 1986 but, in the other years, irrigation effects were small and inconsistent.

Only in 1986 were there significant interactions of cultivar $\times$ ground-cover and cultivar $\times$ irrigation treatments. 'Garnet Beauty' had higher fruit set with sod vs. temporary cover, with the opposite response noted for 'Harbrite' and 'Canadian Harmony'. Fruit set was higher for 'Garnet Beauty' and 'Harbrite' with irrigation than without, while 'Canadian Harmony' had similar fruit set in irrigated and nonirrigated plots.

Annual marketable yields. There was a large and consistent cultivar effect on marketable yield each year (Fig. 4). 'Canadian Harmony' had the highest yield in every year except 1988, when 'Harbrite' had the highest. 'Garnet Beauty' had the lowest yield each year. There was a general decline in yield with tree age, although 'Canadian Harmony' yielded as much in the last year as in the first. The ground-cover effect on marketable yields was much smaller than the cultivar effect and only significant in 1987 and 1988, and then the differences were small. Yield in 1987 was enhanced by sod vs. temporary cover, while the opposite effect was noted in 1988. The irrigation effect on yield was greater than that due to sod. In 1985 and 1986, irrigated trees yielded more than those not irrigated; however, in 1987 and 1988, they yielded less than nonirrigated trees.

Cumulative (1985 to 1989) and average annual marketable

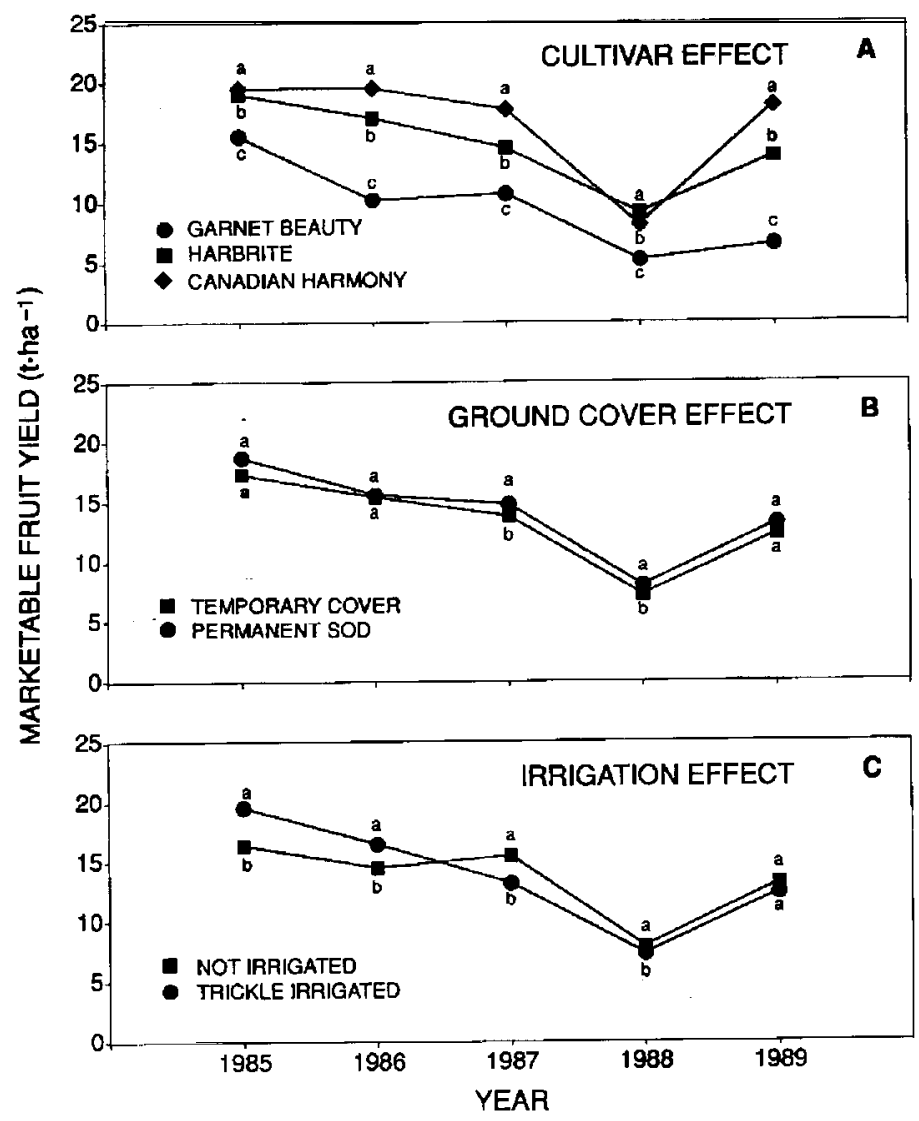

Fig.4. Effect of cultivar (A), ground cover (B), and irrigation (C) treatments on yield of marketable fruit $\left(\mathrm{t} \cdot \mathrm{ha}^{-1}\right)$ from 1985 to 1989 . Mean separation within years within treatments by SEs. yield. 'Canadian Harmony', the late-season cultivar, had the highest cumulative marketable yield (83 t.ha'), 'Harbrite', the mid-season cultivar, was intermediate $\left(73 \mathrm{t} \cdot \mathrm{ha}^{-1}\right)$, and 'Garnet Beauty', the early-season cultivar, had the lowest cumulative yield $\left(48 \mathrm{t} \cdot \mathrm{ha}^{-1}\right)$. Ground-cover and irrigation effects were smaller than cultivar effects. Trees in sod had a cumulative yield of $70 \mathrm{t} \cdot \mathrm{ha}^{-1}$, while those with temporary cover had a yield of $66 \mathrm{t} \cdot \mathrm{ha}^{-1}$. Irrigated trees had a cumulative yield of $69 \mathrm{t} \cdot \mathrm{ha}^{-1}$, while nonirrigated trees had a cumulative yield of $67 \mathrm{t} \cdot \mathrm{ha}^{-1}$.

When the 5 years of yields were averaged by cultivar for the four soil-management treatment combinations, no single treatment combination was best for all cultivars. 'Garnet Beauty' yielded best with sod plus irrigation and poorest with temporary cover plus irrigation. 'Harbrite' yielded best with sod plus irrigation but poorest with sod minus irrigation. In contrast, 'Canadian Harmony' yielded best with sod minus irrigation and poorest with temporary cover plus irrigation.

Yield of marketable large $(>6.35 \mathrm{~cm})$ fruit. There was a large and highly significant cultivar effect on the yield of large fruit (Table 3). 'Canadian Harmony' consistently had the highest yield, 'Harbrite' was intermediate, and 'Garnet Beauty' had the lowest. Ground-cover treatments had no significant effect on yield of large fruit. Yields were similar in irrigated and nonirrigated plots, except in 1989, when nonirrigated plots outyielded irrigated plots.

Yield of marketable medium fruit $(5.40$ to $6.35 \mathrm{~cm})$. There was a significant cultivar effect on yield of medium fruit in 1985, 1987, and 1988 but not in 1986 and 1989 (Table 4). 'Garnet Beauty' generally had the highest average yield for the 5 years $\left(6.0 \mathrm{t} \cdot \mathrm{ha}^{-1}\right)$, 'Harbrite' was intermediate (4.2 t.ha' $)$, and 'Canadian Harmony' had the lowest yield $\left(1.9 \mathrm{t} \cdot \mathrm{ha}^{-1}\right)$. Ground-cover treatments also affected yield, especially in 1985 . However, the average yield in sod for the 5 years was the same as with temporary cover. Yields were higher in irrigated vs. nonirrigated plots in 1985 and 1986, and, when averaged over the 5 years, they were $18.6 \%$ higher than in nonirrigated plots.

Yield of small unmarketable fruit $(<5.4 \mathrm{~cm})$. There was a significant cultivar effect on the yield of small, unmarketable fruit in each year except 1987; however, the response was inconsistent (data not presented). From 1985 to 1987, yields were highest with 'Garnet Beauty' and lowest with 'Canadian Harmony'. In 1988, yields were highest with 'Canadian Harmony' and lowest with

Table 3. Effect of cultivar, ground-cover, and irrigation treatments on yield of large $(>6.35 \mathrm{~cm})$ marketable peaches from the sixth to the 10th year. ${ }^{2}$

\begin{tabular}{lccccc}
\hline \hline & \multicolumn{5}{c}{${\text { Yield }\left(\mathrm{t} \cdot \mathrm{ha}^{-1}\right)}$} \\
\cline { 2 - 6 } Treatment & 1985 & 1986 & 1987 & 1988 & 1989 \\
\hline Main plots & 3.0 & 8.8 & 5.0 & 1.2 & 2.4 \\
$\quad$ Garnet Beauty & 7.2 & 15.5 & 9.8 & 4.9 & 43 \\
Harbrite & 18.1 & 18.9 & 16.5 & 7.2 & 12.6 \\
Canadian Harmony & $* *$ & $* *$ & $* *$ & $* *$ & $* *$ \\
$\quad$ F test & & & & & \\
Subplots & 10.1 & 14.0 & 10.3 & 3.5 & 6.4 \\
$\quad$ No sod & 8.8 & 14.3 & 10.6 & 3.8 & 6.5 \\
Sod & NS & NS & NS & NS & NS \\
$\quad$ F test & & & $\cdot$ & & \\
Sub-subplots & 8.9 & 14.1 & 10.3 & 3.4 & 7.5 \\
$\quad$ No irrigation & 9.9 & 14.2 & 9.6 & 3.9 & 5.3 \\
Irrigation & NS & NS & NS & NS & $*$ \\
F test & & \multicolumn{5}{c}{} \\
\hline
\end{tabular}

${ }^{2}$ Data based on plot totals.

${ }^{\mathrm{Ns}}, *$, **Nonsignificant or significant at $P \leq 0.05$ or 0.01 , respectively. 
Table 4. Effect of cultivar, ground-cover, and irrigation treatments on yield of medium $(5.4$ to $6.35 \mathrm{~cm})$ peaches from the sixth to the 10 th year. ${ }^{\mathrm{z}}$

\begin{tabular}{lccccc}
\hline & \multicolumn{5}{c}{ Yield (t-ha $^{-1}$ ) } \\
\cline { 2 - 6 } Treatment & 1985 & 1986 & 1987 & 1988 & 1989 \\
\hline Main plots & & & & & \\
$\quad$ Garnet Beauty & 12.4 & 2.3 & 5.8 & 5.1 & 4.3 \\
$\quad$ Harbrite & 11.7 & 1.4 & 4.7 & 4.2 & 9.5 \\
Canadian Harmony & 1.5 & 0.4 & 1.2 & 1.1 & 5.2 \\
F test & $* *$ & NS & $* *$ & $* *$ & NS \\
Subplots & & & & & \\
No sod & 7.2 & 1.4 & 3.5 & 3.1 & 5.8 \\
Sod & 4.9 & 1.3 & 4.2 & 3.9 & 6.8 \\
F test & $* *$ & NS & NS & NS & NS \\
Sub-subplots & & & & & \\
$\quad$ No irrigation & 7.4 & 0.4 & 4.2 & 3.9 & 5.6 \\
Irrigation & 9.7 & 2.3 & 3.6 & 3.1 & 7.0 \\
F test & $* *$ & $* *$ & NS & NS & NS \\
\hline
\end{tabular}

${ }^{\mathrm{z}}$ Data based on plot totals.

Ns, ${ }^{* * *}$ Nonsignificant or significant at $P \leq 0.05$ or 0.01 , respectively.

'Harbrite', with tie opposite response occurring in 1989. Over the 5 years, 'Garnet Beauty' had the highest yield of small, unmarketable fruit, whale 'Canadian Harmony' and 'Harbrite' had similar but lower yields. There was a significant ground-cover effect on yield in 1985 and 1988 but not in the other 3 years. In 1985, yield of small fruit was higher in sod vs. temporary cover, while the opposite response occurred in 1988. There was also a significant irrigation response in 1986 and 1989 but not in the other 3 years. In 1986 and 1989, higher yields of unmarketable small fruit were obtained in irrigated plots.

Yield of unmarketable fruit with split pits. In each year, except 1989 , the cultivar effect on yield of split pits was significant but the cultivar response was inconsistent (data not presented). The average annual yield of split pits for 1985 to 1989 was $2.2 \mathrm{t} \cdot \mathrm{ha}^{-1}$ ('Harbrite'), 2.0t.ha" ('Canadian Harmony'), and $1.7 \mathrm{t} \cdot \mathrm{ha}^{-1}$ ('Garnet Beauty' ). There was no effect of ground-cover treatments on yield of fruit with split pits in any year. Irrigation promoted more split pits than no irrigation in 1985 and 1986, while in 1989 the opposite effect occurred.

In 1985, there was a significant ground-cover $\times$ irrigation interaction. Under temporary cover, there were fewer split pits with irrigation than without, while under permanent sod there were more split pits with irrigation than without. In 1987 and 1989, there were significant cultivar $\times$ irrigation interactions, 'Canadian Harmony' had fewer split pits with irrigation than without, while the opposite effect was noted for 'Garnet Beauty' and 'Harbrite'.

\section{Discussion}

From 1985 to 1989 , there was an ample supply of soil water in irrigated plots so that soil water deficits never occurred in these plots (Figs. 1 and 2). In nonirrigated plots, potentially stressful conditions existed in 1985, 1986, and 1988, especially in the top $130 \mathrm{~cm}$ of soil, where total soil water content fell below the PWP (Fig. 1). Wilting of trees was not observed, however. A portion of the root system of 11-year-old peach trees was between 130 to 230 $\mathrm{cm}$ deep, with some roots below the water table at $300 \mathrm{~cm}$ deep (Layne et al., 1986). We propose, therefore, that the failure of peach trees to wilt, although soil moisture in the top $130 \mathrm{~cm}$ fell below the PWP, was because a portion of the root system was deep enough to extract water from below $130 \mathrm{~cm}$ where the water supply was always ample (Fig. 2). Tan and Buttery (1982) showed that, if as little as $25 \%$ of the root volume of peach was adequately watered, water stress was alleviated.

Tree growth (TCA). In the first 5 years of this experiment (Layne and Tan, 1988) and in the subsequent 5 years reported here, the three cultivars had similar growth rates and TCA increased with tree age.

In the first 5 years of this experiment, TCA was generally higher in plots with temporary cover than those with permanent sod strips in the row middles (Layne and Tan, 1988), probably because of increased competition for water and nutrients in the latter treatment. However, as the trees matured between 1985 and 1989, there was less difference between treatments, perhaps because more of the peach root system could exploit water reserves deeper in the soil profile (Layne et al., 1986; Tan and Layne, 199 1). Further, the additional $\mathrm{N}$ applied to the permanent sod plots from 1986 to 1989 compensated for the nutritional stress that would otherwise have developed had the same rates been applied to the two ground-cover treatments as during the first 5 years (Layne and Tan, 1988).

Differences in TCA as a function of irrigation were greater than those due to sod or to cultivar treatments. By the final year (1989), trunks of irrigated trees averaged $9.3 \%$ larger than those not irrigated, while trunks of trees in permanent sod were only $3.6 \%$ larger than those in temporary cover. The irrigation effect on tree size in the last 5 years of growth was less than in the first 5 years (Layne and Tan, 1988). Presumably, when the orchard was younger, more of the root system was closer to the soil surface (Layne et al., 1986; Richards and Cockroft, 1975) and, therefore, may have been exposed to greater soil water stress during the early period than observed here for older trees.

$P n$. Pn measurements were all made in June or July when the early- ('Garnet Beauty' ) and mid-season ( 'Harbrite' ) cultivars were more advanced in their fruit development than the late-season cultivar ('Canadian Harmony'). This difference may explain why Pn was $\approx 20 \%$ lower for the late-season cultivar (Table 1). Further evidence that ground-cover treatments were not very stressful to mature peach trees was that Pn and stomatal conductance values in each of 3 years were similar, even during 1988, when a difference might have been expected based on the differences in total soil water in the top $130 \mathrm{~cm}$ (Fig. 1). Irrigation treatments also had only small effects on Pn and stomatal conductance in 1988. This result again provides indirect evidence that a portion of the root system must have been able to extract sufficient water from deep in the soil profile (Fig. 2) to compensate for the low soil water content nearer to the soil surface (Fig. 1).

Defoliation. Peach cultivars differ in their time and rate of defoliation (Weaver and Jackson, 1963). We have observed that peach trees under stress defoliate sooner and faster than those that are not stressed. Therefore, we were not surprised that, during the hot, dry Summer 1988, trees in permanent sod plots defoliated sooner than trees in temporary cover. Nonirrigated trees defoliated sooner and faster than those in irrigated plots in 4 of the 5 years. Early defoliation in this experiment was a more sensitive plant stress indicator than other measurements.

Winter injury and canker ratings. Layne and Tan (1984) found that irrigated peach trees developed less canker and winter injury and that fewer trees died than nonirrigated trees. Further, nonirrigated plots had the lowest soil water content, and leaf stomatal conductance was significantly lower for nonirrigated trees (Tan and Layne, 1991).

In this experiment, cultivar differences in winter injury were noted in the early years (Layne and Tan, 1988) and corresponded to genetic differences in cold hardiness (Layne, 1982). From 1985 to 1989 , however, cold stress was insufficient to permit discrimi- 
nation of cultivar differences. We do not know why it was only in 1987 that canker was less severe with sod strips in the row middles than with temporary cover. The opposite effect of irrigation on canker was observed earlier in the life of this orchard (Layne and Tan, 1988) and in another experiment involving sprinkler irrigation (Layne and Tan, 1984). In the experiment reported here, canker was more severe in irrigated than nonirrigated plots. These results were supported by the consistently higher tree survival in nonirrigated than irrigated plots from 1985 to 1989 (Fig. 3). Conceivably, the higher rate of irrigation used here (80\% to $100 \%$ ASW) compared to the experiment (Layne and Tan, 1984) with sprinkler irrigation in which lower rates were used $(25 \%$ to $100 \%$ ASW) may have promoted more growth in the fall, which resulted in later defoliation and delayed cold acclimation. These factors presumably contributed to the death of more trees in irrigated plots (Fig. 3). Further, uniformly applied sprinkler irrigation resulted in shallower rooting (Layne et al., 1986), whereas trickle irrigation promoted shallow rooting near the emitters but deeper rooting in soil beyond the wetted emitter zone (Levin et al., 1979). Had irrigation been terminated immediately after the harvest of each cultivar, it may have been more conducive for growth cessation and earlier fall acclimation than the full-season irrigation practiced here.

Flower bud and wood hardiness. Controlled-freezing tests in the laboratory can sometimes provide more discriminating assessments of cold hardiness of FBs and SX than that resulting from natural injury outdoors (Layne, 1982, 1984, 1989). While no differences in winter injury based on field ratings were detected, cultivar and irrigation effects were measured in controlled-freezing tests (Table 2). 'Canadian Harmony' flower buds were consistently the least hardy. Irrigated trees had less-hardy flower buds than those not irrigated. Delayed fall acclimation, especially the early-season 'Garnet Beauty', may have resulted from full-season irrigation, with higher soil water content promoting more active growth in the fall. Reduced tree survival in the irrigated plots (Fig. 3) support this conclusion.

Tree survival. Tree survival was a function of cultivar, groundcover, and irrigation treatments. 'Garnet Beauty' had the poorest tree survival of the three cultivars in 1988 and 1989 (Fig. 3). 'Garnet Beauty' was also the earliest ripening cultivar, thus having a longer period without the competition of a crop on vegetative growth. This pattern may have resulted in more vegetative growth later in the season and delayed hardening in the fall, with increased vulnerability to cold injury in this cultivar. 'Garnet Beauty' also had more canker infection than 'Canadian Harmony' in 1988, a response that would have increased its vulnerability to further canker and winter injury in 1989 (Biggs, 1989; Dhanvantari, 1978; Layne, 1984). Permanent sod strips in the row middles provided greater protection to peach roots by trapping and retaining snow cover longer and ameliorating soil temperatures in winter more than temporary cover, possibly improving tree survival. Water infiltration into the soil is reported to be better with permanent sod than with bare ground or temporary cover (Welker and Glenn, 1988).

Blossom intensity and fruit set. Blossom intensity was a reflection of relative bud hardiness of the three cultivars (Table 2) and generally agreed with hardiness levels normally attributed to them (Layne, 1982). Blossom intensity usually predicted fruit set ratings, since frost or other unfavorable postbloom environmental conditions did not occur during the experiment.

Marketable yield. Canker and winter injury contributed to the decline and death of peach trees in this experiment (Fig. 3), thereby reducing annual (Fig. 4) and cumulative yields. Similar results were found in an earlier experiment in the same soil type (Layne and Tan, 1984). The longer period available for accumulation of photo assimilates in the mid- and late-season cultivars (De Jong, 1986a, 1986b), along with their better tree survival (Fig. 3) compared with the early-season 'Garnet Beauty', contributed to their higher yields (Fig. 4). The cultivar effect on yield was greater than either the ground-cover or irrigation effects, as was found in early years of the experiment (Layne and Tan, 1988). Mature trees with a more extensive root systems seemed more tolerant of stress than younger trees (Layne and Tan, 1988), whose root systems were presumably restricted to the soil surface (Layne et al., 1986).

Fruit size and grade. Fruit size was significantly affected by cultivar, ground-cover, and irrigation treatments, a result supporting findings from earlier in the life of this orchard (Layne and Tan, 1988) and in other experiments (Chalmers et al., 1981, 1983; Layne and Tan, 1984). The largest differences in fruit size were due to cultivar effects and reflected their genetic differences in duration of fruit development (R.E.C. Layne, unpublished data). Ground-cover and irrigation effects were less consistent. The 1989 growing season was wetter than the previous-ones, and irrigated trees may have had too much water and may have depressed yields of large fruit compared with nonirrigated trees (Chalmers et al., 198 1). The incidence of split pits was affected by all main factors and their interactions and was a better indicator of stress than fruit size.

\section{Conclusion}

In devising an orchard management system for high-density peaches, it is best if the cultivar, ground-cover, and irrigation effects are independent and additive, as was found for an earlier study (Layne and Tan, 1984). This permits a single management system to be used effectively for all cultivars. If there are major and consistent treatment interactions, then greater care must be exercised in developing an appropriate management strategy.

In the last 5 years of this experiment, there were several significant treatment interactions. Cultivar $\times$ ground-cover interactions affected fruit set, TCA, and tree survival, while cultivar $\times$ irrigation interactions affected blossom intensity, fruit set, split pits, and tree survival. The effects of ground-cover and irrigation treatments were usually independent of each other. There was no single ground-cover and irrigation combination that was optimum for all three cultivars. When the three most important variables were considered together (i.e., TCA, survival, and marketable yield), the optimum system for 'Garnet Beauty', the early-season cultivar, was permanent sod strips in the row middles with trickle irrigation in the tree row. For 'Harbrite', the mid-season cultivar, temporary cover without irrigation (the commercial practice) was best, while for 'Canadian Harmony', the late-season cultivar, permanent sod strips in the row middles without supplemental irrigation was best. The poorest system for 'Garnet Beauty' and 'Canadian Harmony' was temporary cover with trickle irrigation, while the poorest system for 'Harbrite' was permanent sod with irrigation.

During the first 5 years of this experiment, the optimum soilmanagement system for all cultivars was permanent sod strips in the row middles and trickle irrigation in the tree row (Layne and Tan, 1988). While this system was no longer the best for all three cultivars during the second 5 years, it was equally effective as temporary cover without irrigation and better than permanent sod without irrigation or temporary cover with irrigation.

Permanent sod strips in the row middles promote tree survival and provide several advantages over the conventional system (Glenn and Welker, 1989; Hogue and Neilsen, 1987; Layne and Tan, 1988; Marks et al., 1983; Townshend et al., 1984; Welker and Glenn, 1988). Trickle irrigation was clearly advantageous during 
the first 5 years of orchard establishment and early production (Layne and Tan, 1988), but became less important during the next 5 years. We postulate that, during this latter period, a portion of the root system, especially in nonirrigated plots, could access ample water reserves below $130 \mathrm{~cm}$ in the soil profile, thereby alleviating drought stress.

\section{Literature Cited}

Biggs, A.R. 1989. Integrated approach to controlling Leucostoma canker of peach in Ontario. Plant Dis. 73:771-773.

Bittenbender, H.C. and G.S. Howell, Jr. 1974. Adaptation of the Spearman-Karber method of estimating the $\mathrm{T}_{50}$ of cold stressed flower buds. J. Amer. Soc. Hort. Sci. 99:187-190.

Chalmers, D.J., P.D. Mitchell, and L. van Heek. 1981. Control of peach tree growth and productivity by regulated water supply, tree density, and summer pruning. J. Amer. Soc. Hort. Sci. 106:307-312.

Chalmers, D. J., K.A. Olsson, and T.R. Jones. 1983. Water relations of peach trees and orchards, p. 197-233. In: T.T. Kozlowski (cd.). Water deficits and plant growth. vol. 8. Academic Press, New York.

Daniell, J.W. 1982. Effect of trickle irrigation on the growth and yield of 'Loring' peach trees. J. Hort. Sci. 57:393-399.

De Jong, T.M. 1986a. Fruit effect of photosynthesis in Prunus persica. Physiol. Plant. 66: 149-153.

De Jong, T.M. 1986b. Effects of reproductive and vegetative sink activity on leaf conductance and water potential in Prunus persica (L). Batsch. Scientia Hort. 29:131-137.

Dhanvantari, B,N. 1978. Cold predisposition of dormant peach twigs to nodal cankers caused by Leucostoma spp. Phytopathology 68:1779-1783.

Glenn, D.M. and W.V. Welker. 1989. Orchard management systems influence rainfall infiltration. J. Amer. Soc. Hort. Sci. 114:10-14.

Hogue, E.J. and G.H. Neilsen. 1987. Orchard floor vegetation management, p. 377-430. In: J. Janick (cd.). Horticultural reviews. vol. 9. Van Norstrand Reinhold, New York.

Layne, R.E.C. 1982. Cold hardiness of peaches and nectarines following a test winter. Fruit Var. J. 36:90-98.

Layne, R.E.C. 1984. Breeding peaches in North America for cold hardiness and perennial canker (Leucostoma spp.) resistance-A review and outlook. Fruit Var. J. 38:130-136.

Layne, R.E.C. 1989. Breeding cold hardy peach cultivars for Canada.
Acta Hort. 254:73-78.

Layne, R.E.C. 1991. The variety picture for apricots, peaches and nectarines in the Great Lakes region. Proc. New York State Hort. Soc. Annu. Mtg. 136:113-124.

Layne, R.E.C. and C.S. Tan. 1984. Long-term influence of irrigation and tree density on growth, survival, and production of peach. J. Amer. Soc. Hort. Sci. 109:795-799.

Layne, R.E.C. and C.S. Tan. 1988. Influence of cultivars, ground covers, and trickle irrigation on early growth, yield, and cold hardiness of peaches on Fox sand. J. Amer. Soc. Hort. Sci. 113:518-525.

Layne, R. E.C., C.S. Tan, and R.L. Perry. 1986. Characterization of peach roots in Fox sand as influenced by sprinkler irrigation and tree density. J. Amer. Soc. Hort. Sci. 111:670-677.

Levin, I.R., R. Assaf, and B. Bravdo. 1979. Soil moisture and root distribution in an apple orchard irrigated by ticklers. Plant \& Soil 52:31-40.

Marks, CF., W.J. Saidak, and P.W. Johnson. 1973. Effects of soil management on numbers of root-lesion nematode Pratylenchus penetraus in soils of Ontario peach orchards. Can. J. Plant Sci. 53:18 1-1 85.

Reeder, B.D., J.S. Newman, and J.W. Worthington. 1979. Effect of trickle irrigation on peach trees. HortScience 14:36-37.

Richards, D. and B. Cockroft. 1975. The effect of soil water on root production of peach trees in summer. Austral. J. Agr. Res. 26: 173-180.

Tan, C.S. and B.R Buttery. 1982. The effect of soil moisture stress to various fractions of the root system on transpiration, photosynthesis, and internal water relations of peach seedlings. J. Amer. Hort. Sci. 107:845-849.

Tan, C.S. and R.E.C. Layne. 1990. Irrigation scheduling for fruit crops. Ontario Ministry Agr. Food Agdex 210/560.

Tan, C.S. and R.E.C. Layne. 1991. Soil water content and stomatal conductance in a mature peach orchard as influenced by various irrigation regimes. Can. J. Soil Sci. 71:253-258.

Townshend, J. L., R.A. Cline, V.A. Dirks, and C.F. Marks. 1984. Assessment of turf grasses for the management of Pratylenchus penetrans and Pratylenchus projectus in orchards. Can. J. Plant Sci. 64:355-360.

Weaver, G.M. and H.O. Jackson. 1963. Genetic differences in leaf abscission and the activity of naturally occurring growth regulators in peach. Can. J. Bot. 41: 1405-1418.

Welker, W.V. and D.M. Glenn. 1988. Growth responses of young peach trees and changes in soil characteristics with sod and conventional planting systems. J. Amer. Soc. Hort. Sci. 113:652-656. 